\title{
The Slow Road to a New Home: The Experiences of the First Generation of South Sudanese Western Australians Settled in Perth ${ }^{1}$
}

Francesca Perugia School of Design, Faculty of Arts, Business, Law and Education, University of Western Australia, Perth francesca.perugia@research.uwa.edu.au

\begin{abstract}
Most refugee migrants entering Australia have limited financial resources. In Australia, low-income migrants from non-English speaking backgrounds - also referred to as Culturally and Linguistically Diverse (CaLD) migrants - feature as one of the groups suffering from the current Australian housing crisis, experiencing difficulty in navigating the housing market and achieving sustainable housing outcomes. This article analyses the case study of the South Sudanese migrants and profiles this group, analysing factors that contribute to improving their financial independence (education, employment and income) and housing outcomes, with the aim to evaluate their overall economic position in relation to accessing the housing market. Data shows that after an average of ten years beginning from their initial arrival in Australia, this migrant group is still struggling to improve their financial position. The article concludes by questioning the current approaches to the resettlement process concerning the attainment of suitable housing outcomes.
\end{abstract}

\section{Introduction}

For the fourteenth time consecutively, the Annual Demographia International Housing Affordability Survey (2018) scored Australian housing markets as severely unaffordable. ${ }^{2}$ Australia has been experiencing housing market affordability problems since the 1990s. However, the housing scene in Western Australia (WA), and Perth, in particular, has

\footnotetext{
${ }^{1}$ I would like to thank my colleagues and mentors at the University of Western Australia who provided valuable comments and suggestions during the process of researching, writing and revising this article. A special thanks goes to Dr Isabel Rousset for always be supportive and critical of my work.

2 This survey rates housing affordability using the "median multiple" which is calculated dividing the median house price by the gross annual median household income.
} 
changed since the early 2000 s, with the effects of the crisis alleviated by an increase in the rental vacancy rates and a decrease in both median rental and sale housing prices. Even if the peak of the housing crisis has passed, affordability problems remain across Australia, especially for low-income households. As Madden and Marcuse observe, "the idea of crisis implies that inadequate or unaffordable housing is abnormal, a temporary departure from a well-functioning standard. But for working-class and poor communities, housing crisis is the norm" (2016, p. 9). This article investigates the experience of one of these low-income communities. It studies the first generation of South Sudanese migrants that have settled in the metropolitan area of Perth (WA). This study is part of a comprehensive investigation into the South Sudanese migrants' territorial distribution and their housing choices within Greater Perth, the major urban conurbation in WA. The settlement of this group of migrants in WA coincided with the increased African refugee migration to Australia. Between the late 1990s and the early 2000 s, Australia opened its door to refugees from African countries involved in enduring civil conflicts and wars. Since their initial settlement in Australia, the Sudanese ${ }^{3}$-born population has rapidly increased in number-more than any other refugee group from the African continent. During the decade up to 2011, almost 27,000 Sudanese people permanently resettled in Australia (DSS 2014). As Robinson (2013, p. 17) notes, "For many Australians, South Sudanese are the face of Africans in Australia". Between 2001 and 2006, Perth welcomed $11 \%$ of the Sudanese entrants, third after Melbourne (33\%) and Sydney (21\%) (DIAC 2007). Moreover, according to the 2011 census data, WA recorded the highest density of Sudan and South Sudan-born people: 1.43 per 1,000 (Robinson 2013). In 2006, Perth $^{4}$ was home to almost $99 \%$ of the Sudanese population present in WA, and according to the most recent census (ABS 2016b), these figures have not changed much over time with $98 \%$ of the Sudanese population in WA still settled in Perth.

Using the three latest Australian Bureau of Statistics (ABS) Census databases (2006, 2011 and 2016), ${ }^{5}$ in this paper I analyse data relative to demographics, education, employment and income to evaluate advancement in economic independence over time, and therefore to assess the increase in

3 From here on, when using the term 'Sudanese' population, I refer to the sum of Sudanand South Sudan-born populations, as per census data.

4 Perth refers to the Greater Perth metropolitan region, identified for statistical purposes in the ABS (2011) "2901.0.Census Dictionary, 2011" and represents the functional extent of WA's capital city and labour market, including Mandurah and Pinjarra areas.

5 Findings are based on ABS TableBuilder census data: see ABS (2006b), ABS (2011b), and ABS (2016b). 
opportunities and choices for the Sudanese population when accessing the housing market. The considered census years correspond to the main stages of the settlement of this ethnic group in WA, allowing for a precise description of their settlement process. The year 2006 corresponds to the initial large-scale arrival of Sudanese refugees in Australia, the year 2011 to a stabilisation in the number of Sudanese entrants following the initial migration peak, and the year 2016 to a period of continued settlement, permitting an evaluation of the settlement outcome - as the majority of Sudanese migrants have, at this point, lived in Perth for at least five years. The paper opens by discussing the current experience of refugee migrants in finding suitable housing. I then explain the research methodology discussing research findings by analysing the demographic profile, income, work, and level of education, including language skills, of the Western Australian Sudanese population. The data shows that the first generation of Sudanese migrants settled in WA have had a slow start in reaching economic independence and therefore in emerging from below the poverty line even after having been in Australia for five to ten years. I conclude by discussing and querying the current literature, which suggests an average of only five years for a complete resettlement process.

\section{Resettlement, Housing and Home}

Most refugee migrants entering Australia have limited financial resources and rely on social housing when looking for accommodation. However, in the timeframe considered in this study, the demand for social housing significantly exceeded the supply, leaving no options for migrants other than seeking affordable private housing opportunities in a rental market where affordability represented only a marginal share (Lejukole 2013; Australian Human Rights Commission 2010). Migrants arriving at the beginning of the new century to Australia experienced the "lack of affordable housing in the private rental market; the tightening of eligibility for public housing; long waiting lists for public housing; and a decrease in public housing stock" (Fozdar and Hartley 2013, p. 6). Adding to this long list, they also faced "a lack of knowledge regarding tenancy issues; the need to be employed; lack of capital and low incomes" (Fozdar and Hartley 2013, p. 6). Moreover, refugee entrants had: a) difficulty in applying for rental property due to lack of rental history or references and/or language barriers; b) trouble in finding suitable housing regarding size and location (accommodating large families and single men in particular); c) struggles with unrealistic expectations and/or suffering the after-effects of torture and trauma; and d) suffer from discrimination from landlords and real estate agents (RCOA 2013; Fozdar 
and Hartley 2012; OMI 2009; Pittaway, Muli, and Shteir 2009; Colic-Peisker and Tilbury 2008). Fozdar and Hartley (2013) note that discrimination is especially relevant for "visibly" different migrants. Similarly, the Australian Human Rights Commission (2010, p. 24) remarks that "racial discrimination - both direct and indirect - was the most common barrier that African Australians said they faced when attempting to find affordable and appropriate housing".

These disadvantages have a profound meaning for migrants. Existing scholarship emphasises the crucial role of "home" and "homemaking processes" in migrants' settlement experiences. The literature identifies the dwelling as the setting for the development of complex socio-spatial relations connected to feelings of belonging and expressions of cultural identity (Azriel 2010; Hadjiyanni 2007; Graham and Connell 2006; Head, Muir, and Hampel 2004; Jacobs 2004; Kiliçkiran 2003; Jacobs 2011). As Kiliçkiran (2003) explains, the house is the primary environment where migrants establish roots in the new country through revived home country habits, while also expressing personal changes. For refugee migrants, the homemaking process goes beyond the individual and emotional experience. Firstly, safe, secure and affordable housing is a fundamental human right for humanitarian entrants - as recognised by the UN Committee on Economic Social and Cultural Rights (1991). Secondly, as pointed out by the UNHCR (2002) in Refugee Resettlement: An International Handbook to Guide Reception and Integration, housing "provides a base from which resettled refugees can seek employment, re-establish family relationships and make connections with the wider community" (p. 162). As Ager and Strang (2008) have pointed out, for this specific group of migrants, housing is both a marker to measure integration and a means to achieve it.

\section{Research Design: Choices and Challenges}

This study uses the three latest available Census databases compiled by the Australian Bureau of Statistics (ABS) to profile the identified ethnic community. For each census, the research has interrogated the datasets: "Counting Persons, Place of Enumeration", "Counting Persons, Places of Usual Residence" and "Counting Employed Persons, Place of Work". The biggest hurdle was to identify the target group. In the 2006 census, the search was limited to the people who indicated their country of birth as "Sudan". For the other two censuses (2011 and 2016), the country of birth used was both "Sudan", and "South Sudan". This decision was taken for two main reasons, the first being associated with the inaccuracy of the census data-in particular, the 2011 census - and the second, related to comparability of data 
across the different census databases (as well as databases from different sources). The 2011 census introduced, for the first time, the preference "South Sudan" in the question relative to "Ancestry" and "Country of Birth". This change in codes aimed to generate an opportunity to understand the extent of South Sudanese migration into Australia. However, as Robinson (2013, p. 15) warns, "the raw data for country of birth is not plausible since they suggest that over 3,000 people [...] born in South Sudan after 9 July 2011 (Independence Day) were residing in Australia one month later (9 August 2011, Census Night)". Robinson also explains that more problems surface when cross-referencing different data in the census database such as language and ancestry. Additionally, the 2011 Census presented issues related to errors in transcriptions, respondents' language barriers, and incomplete and/or incorrectly completed census forms. The data emerging from the 2011 census also presents considerable incongruences in counting the numbers of Sudan- and South Sudan-born population in WA when compared to the successive censuses. While the growth of the total Sudanese born community between the two latest censuses registered only a marginal $5 \%$ increment (corresponding to 200 people), the distribution between the two countries has considerably changed. In 2011, there were 438 South Sudanese and over 2,600 Sudanese-born people residing in the Perth metropolitan area; five years later the census counted over 2,100 South Sudanese and just over 1,100 Sudanese. As this growth in the number of the South Sudanese migrants does not correspond to any interstate migration of considerable proportion, it only confirms Robinson's (2013) hypothesis of the presence of significant errors of estimate of South Sudanese presence in Australia by the 2011 census. Therefore, the study considers the broader category of Perth ${ }^{6}$ residents born in Sudan and South Sudan.

\section{The WA Sudanese Population}

As previously stated, in 2006, Perth was home to almost $99 \%$ of the Sudanese population present in WA. These figures have not changed over time. In 2016, approximately $98 \%$ of the Sudanese population in WA had settled in Perth, with most entering Australia in the decade between 2000 and 2010, during the second wave of Sudanese migration to Australia. The increased Sudanese migration to Australia was prompted by the escalation of Sudan's longstanding civil war, combined with the UNHCR pressure on the Australian Government to increase the number of refugees accepted into the country, and the " $9 / 11$ effect" which shifted the intake of refugees out of the

${ }^{6}$ From now on, when using the term Perth, the article refers to the Greater Perth Metropolitan Area as identified in the 2011 and 2016 censuses. 
Middle Eastern region for security reasons (Robinson 2013; Hugo 2011; Dhanji 2010; Hart and Maiden 2007).

The analysis of data from the three latest censuses, aggregated per year of arrival, suggests that the Sudanese migration to WA started in earnest in the early 2000s, peaked between 2003 and 2007, and then abated in recent years (Figure 1). In 2011, 3,208 Sudan- and South Sudan-born people lived in WA (ABS 2011c), registering a 57\% growth compared to 2006. Between 2011 and 2016 data show that (first generation) Sudanese migrants in WA has now settled, with the latest Census (2016) registering only a marginal 5\% growth over the previous 5 years. It is important to note that some of this population initially settled elsewhere in Australia. Data on internal migration across Australian States and Territories show that in 2011, 8\% of the Sudanese people in WA migrated from within Australia, with the majority of them coming from New South Wales (32\%) and Victoria (30\%) (Census 2011).

According to the 2006 census, the first WA Sudanese settlers were young (91.5\% under the age of 44$)$ and predominantly Christian (81.6\%). This profile has only minimally changed during the rapid increase of Sudanese migration registered leading up to 2011. The demographic statistics of the Sudanese population, in 2011, show in fact that the newly arrived migrants were in the same age bracket of their predecessors and we can attribute the increase of average age - as visible in Figure 2 - to the natural ageing of the population.

While the fundamental demographic characteristics (sex and age) of this migrant group have not changed significantly in the considered decade, a significant change has occurred in household composition. In 2006, 30\% of the Sudanese population was married, and $7 \%$ of people lived in a singleparent household. Families encompassed both dependant and non-dependent children as well as immediate family. In 2006, $10 \%$ of Sudanese were living with their relatives*; and a very marginal number of people lived alone (4\%) or in shared housing $(2 \%)$.

In time, the household composition and family living arrangement started changing. The absolute number of lone parents doubled between 2006 and 2011. Analogously, in this period, the number of people living with unrelated families doubled. Demographic changes related to household composition continued to occur in the following five years. Overall, between 2006 and 2016, the number of married Sudanese (opposite-sex couples) doubled, and the number of people living in a single parent household quadrupled. While in 2006 there were two married couples for each lone parent, in 2016 the ratio dropped to $1: 1.3$. This coincided with an increase in the number of "separated" people. In 2016, the number of separates was, in fact, four times 
in value when compared to data collected ten years earlier. In the decade considered, census data also register a decrease of large families (six or more) and an increase in the number of people living in smaller households (two and three family members) (Figure 3). This change in the number of people counted in the household can be partially attributed to changes in family structures due to divorce and separation, and adult progeny still living in the household. Since settlement, the population presented an almost equal distribution between the two sexes (Figure 2). However, disparities within this migrant group between sexes are evident in education, participation in the workforce and proficiency in spoken English. Sudanese-Australian women have a lower level of education compared to their male counterparts, with an average, across the three censuses, of $19 \%$ difference between men and women having completed year 12 or equivalent (Table 1).

An even higher difference in percentage between the two sexes is evident concerning school attendance. On average, across the three censuses, $3 \%$ of men and $13 \%$ of women never attended school. Women remained also less proficient in speaking English. In 2006, 31\% of the Sudanese women did not speak English well (and 6\% spoke no English at all); while, for men, about $17 \%$ did not speak English well. Five years later, $21 \%$ of women were still not fluent in spoken English (9\% for men), and in 2016 the percentage dropped to $16 \%$ (5\% for men). Sudanese women are also less active in the workforce. In 2006, 71\% of them did not work and in 2011 this percentage diminished by $11 \%$. Data on male employment show that Sudanese men are, on average, four times more engaged in a full-time job than Sudanese women are. However, they still have a higher percentage of unemployment compared to Perth's overall male population (four times). In 2006-2011, half of the Sudanese-Australian population - specifically half the number of Sudaneseborn people responding to the workforce section of the census-was not in the labour force (Table 2). The male Sudanese workers were mainly employed in the manufacturing industry ( $40 \%$ in 2006 , decreasing to $32 \%$ in 2011 ), while women worked primarily in healthcare and community services (45.8\% women in 2011, a figure that had doubled compared to 2006). The relatively high level of unemployment among Sudanese Australians is partly explained by the involvement of Sudanese migrants in some form of study. Almost invariably across the 2006 to 2016 decade, approximately a third of the total Sudanese population aged twenty to sixty-nine attended an educational institution (mainly university and tertiary institutions) and, of these students two-thirds were enrolled full-time*. 


\section{The Slow Way Home}

High levels of unemployment and commitment to study among Australian-Sudanese culminate in low personal and household incomes. The slow growth in economic independence is reflected in limited housing choices and housing stress. At the time of the 2006 census, $76 \%$ of the Sudanese population aged fifteen and over was earning a weekly gross income less than the average WA weekly income, which at the time was set at $\$ 861.30$ (ABS 2006a).

Five years later, despite a general increase in the percentage of Sudanese above the age of fifteen earning higher salaries, still fully $84 \%$ of them relied on a weekly income that was below the state average of $\$ 1,138.90$ (ABS 2011a). Similarly, in 2016, despite the Sudanese population continuing to increase their weekly income, the vast majority (86\%) remained below the average state weekly income of $\$ 1,205.30$ (ABS 2016a)*. The meaning of the term low-income for this migrant group is, however, better understood when comparing their equivalised gross weekly household income ${ }^{7}$ with the mean equivalised disposable household income in Australia. ${ }^{8}$

In $2006,88.7 \%$ of the Sudanese population in WA had a household income below the second lowest quintile value calculated for the 2005-06 financial year, of $\$ 640$ (valued at 2006). For the same period, the mean equivalised disposable household income per week for low-income earners was calculated as $\$ 341$ (ABS 2007a), and the cost of housing occupancy for

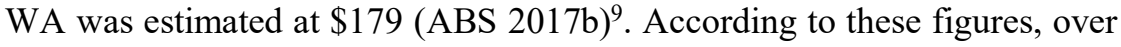
$80 \%$ of the Sudanese population was living in poverty. In 2011, the value of the low-income category in the household income distribution rose to $\$ 496$ (ABS 2017a). Seventy-six percent of Perth's Sudanese population were living in a household with a gross income lower than the set value defining low-income. This value increases to $89 \%$ when including Sudanese

\footnotetext{
7 This is defined by the ABS as: “'Total income' at the household level adjusted using an equivalence scale. This variable has been developed to enable comparison of the relative incomes of households of different sizes and composition. When household income is adjusted according to an equivalence scale, the equivalised income can be viewed as an indicator of the income available to a standardised household or as an indicator of the resources available to each individual in a household" (ABS 2015).

8 This has been done by using the quintile categories estimated by the ABS (2017a) for the period from 1994-95 to 2015-16. The values indicated by the ABS are adjusted to 2015 dollars value using the Consumer Price index (CPI). The values indicated in Table 3 have been re-adjusted using the ABS CPI inflation calculator, http://www.abs. gov.au/websitedbs/d3310114.nsf/home/Consumer+Price+Index+Inflation+Calculator using the annual index.*

9 All household renting.
} 
households with a gross income below the estimated second lowest quintile value. Data has not changed much in 2016, with first generation Sudanese migrants in Perth - at almost ten years since their arrival — still within the low-income category.

Both in 2011 and in 2006, 80\% of Sudanese migrants lived in single detached dwellings with the residual $20 \%$ residing in semi-detached houses and flats*. According to the census data, in 2011, 70\% of the Sudanese migrants lived in rental properties, while the remaining either were paying a mortgage $(20 \%)$ or owned their house outright $(3 \%)$. Analysing the census data, it emerges that the tenure type relates to the year of arrival in Australia and the area of settlement. Analysing relative percentages of tenure type by year of arrival, a correspondence between the length of stay in Australia and tenure is evident (Table 4). Moving backwards on the timeline, the proportion of homebuyers increases on an annual basis.

The proportion of the total number of Sudanese migrants buying a home doubled between 2006 and 2011, while the rate of Sudanese living in a rental property registered only a $10 \%$ decrease. Such disparity in percentages can be attributed to the increase of the Sudanese migrant population in Australia between the two censuses. However, a more thorough analysis of the data shows that $60 \%$ of these renters were migrants that had been living in Australia for five or more years. Between 2011 and 2016, the WA Sudaneseborn population registered only a marginal $5 \%$ growth. By this time, migrants had started expressing the desire to remain in Perth, with an increased number of them investing their small income in buying a home.

Given their low-income and precarious job position, renting offers them an opportunity to move between different properties in order to locate more affordable housing. The recording of a significant share of migrants renting after several years of settlement needs contextualising within the problem of inaccessibility to the Perth housing market as well as the characteristics of the migrant group considered. In his study of the first and second generation of migrants in Australia, Hugo (2011) suggests that, in interpreting data relative to migrants' housing tenure, both their average age and the presence (or absence), of an established migration pattern to Australia needs to be considered. He argues that home ownership rates are lower in younger age groups and that more recently arrived migrant groups have lower ownership rates compared to established ones. Perth's Sudanese migrant population ticks both of these boxes. As the age chart above (Figure 2) shows, the Sudanese population settled in Perth is young, with over $90 \%$ of the population being forty-four years old or younger. Moreover, the arrival of refugee Sudanese people to Australia is relatively recent with a steady influx 
of entries registered only in the early 2000s. Nevertheless, independently from the tenure type, a considerable share of both renters and owners invested a substantial portion of their income to pay for their accommodations, indicating severe housing stress. This is clear in the data summarised in Tables 5 and 6 , which respectively compares the housing income of the Sudanese born population with rent and mortgage repayment. ${ }^{10}$ It is worth pointing out with regard to home purchase, that the choice of Sudanese migrants to buy a house even if not financially fit for the recurrent and longterm cost, is not an isolated choice. Hugo (2011, p. 157) noticed a similar pattern for Vietnamese, Laotian, and Cambodian migrants, observing that that they were "reproducing a pattern of earlier generations of low skilled migrants who placed a high priority on property purchase". A very high proportion of the Sudanese population lived in a household where the cost of the weekly rent was higher or equivalent to its gross equivalised income*. The ABS (2007) calculated that, for the financial year 2005-06 in WA, the housing cost for private renters was equivalent to $16 \%$ of their gross income. In 2006, low-income Sudanese migrants, however, were spending more than $16 \%$ of their income to pay their rent. According to the figure elaborated in the 2006 census data (summarised in Table 7) the percentage value is considerably higher, with a large number of Sudanese households investing $50 \%$ or more of their household income to pay the rent. This data assumes more significance when contextualised within the cost of rental property, using a snapshot at the time of the 2006 census. The analysis of the cost of the rental housing stock in the private market at the 2006 census night, in fact, emphasises the extent of the difficulties experienced by migrants in finding economically viable private rental opportunities.

\section{Conclusions}

At their arrival (as charted by the 2006 Census), the Sudanese migrant population that settled in Perth were relatively young individuals with a refugee background and a low-income economic profile. After 5 years, according to the 2011 Census, their demographic profile had not changed significantly nor had their financial position. According to the analysed census data, the vast majority of the Sudanese population in fact in 2011 still relied on an income significantly lower than the average weekly WA salary. In 2016, despite the Sudanese migrants having significantly improved their economic position, still almost $90 \%$ of the first-generation population was

10 To note that to calculate the percentages the highest values of the range has been used. As mortgage is calculated monthly in census data the month length of 4 weeks has been considered and the value has been divided accordingly. 
earning a weekly salary lower than the average State weekly income. The data presented shows that since their arrival the first generation of Sudanese migrants have improved their employment status, education level, and increased their income. However, the vast majority of them after ten years living in Australia were still struggling to better their financial position to a level where they could detach themselves from the label of "low-income migrant group". These findings highlight the necessity for further research regarding the resettlement experience of other migrant groups-also considering different geographical locations and timeframes - in relation to building financial independence. Moreover, this initial exploration of the census data exposes differences in progress (both in relation to education, and therefore to job status) between male and female, with the latter advancing at much slower pace when compared to their male counterparts. The analysis of the data relative to income has not been investigated in relation to gender; however, the type of jobs in which the female Sudanese population is employed (healthcare and community services sectors) suggests roles with a low hourly pay rate.

The migrant group considered in this study has mostly entered Australia with a Humanitarian Visa, and are therefore eligible at arrival for the assistance provided by the Australian Government through the Refugee and Humanitarian Program (HSS). Under the direction of the Department of Immigration and Border Protection, the program establishes eligibility criteria and regulates the number of entrants. According to the program, the procurement of a six-month lease is considered a satisfactory outcome and contributes to fulfilling the requirements to exit the HSS. As part of the housing assistance package, the program offers a one-time grant and rental assistance (up to six months); and groups such as religious organisations and migrant welfare bodies provide additional help. Following the initial period, Centrelink ${ }^{11}$ offers further assistance. Notwithstanding the structure put in place by the government to provide adequate housing, as well as guarantee control over the quality of the support offered, the reality of the resettlement comprises many hurdles (RCOA 2013, Fozdar and Hartley 2012, 2013, 2013a, Australian Human Rights Commission, 2010). The Department of Social Services (DSS 2016) itself recognises the difficulty for migrants in finding and accessing affordable and adequate housing. In a booklet targeting newly arrived migrants the Western Australia government acknowledges "Housing in Australia can be difficult to find and rent can be expensive. It may be particularly difficult for large families to find long-term

11 Centrelink is a program within the Australian Department of Human Services that delivers social and welfare payments and services. 
accommodation that suits all their needs" and advising the migrants, "You may need to compromise and take housing that is available" (DSS 2016, p. 64).

Taking what is available is indeed the best way to describe the housing choices of Sudanese refugees settled in Perth. The report of the WA Office of Multicultural Interests (OMI) on the settlement of African humanitarian entrants in WA states that at arrival, migrants "were having difficulty securing government and/or private housing after the six-month lease expired" (OMI 2009, p. 37). Participants in the OMI study also reported "lengthy waiting times for government housing and difficulties securing accommodation for large families" with some of them resorting "to leasing two separate dwellings to house their families" and facing "barriers accessing private housing", which included "cost, lack of referees and racism" (OMI 2009, p. 37).

A study carried out for the Department of Immigration on first- and second-generation humanitarian entrants (Hugo 2011) stresses that it is approximately within the first five years after their arrival that refugee migrants establish themselves in their new country. In this period, they are seeking rental opportunities rather than home ownership because they have minimal house-buying power: they are most likely to be involved in some form of study and/or they are at the initial stage of building their working career. This profile coincides with the Sudanese refugees settled in WA. However, this timeframe, still primarily used as a reference in Australian migrant literature, is questioned by the findings of this study. These findings call for more research on the resettlement experience of other migrants' groups and a rethinking of settlement services provided in relation to the length of wait times before services are accessible, and the nature of services offered.

In summary, the findings of the study presented in this article show the relatively slow process of Sudanese-Australian migrants in bettering their economic situation. The data also indicates that the precarious financial status is paired with the experience of a high percentage of Sudanese migrants established in Perth between 2006 and 2016 spending a prolonged period in rental accommodation with only a small percentage of them attempting the financial risk of accessing the house-buying market, even when not supported by an adequate income. These findings open up a debate surrounding issues about how the current resettlement process is managed, and the opportunity for migrants to complete it successfully, which includes the capacity to access and maintain a suitable housing outcome within a shorter timeframe. 


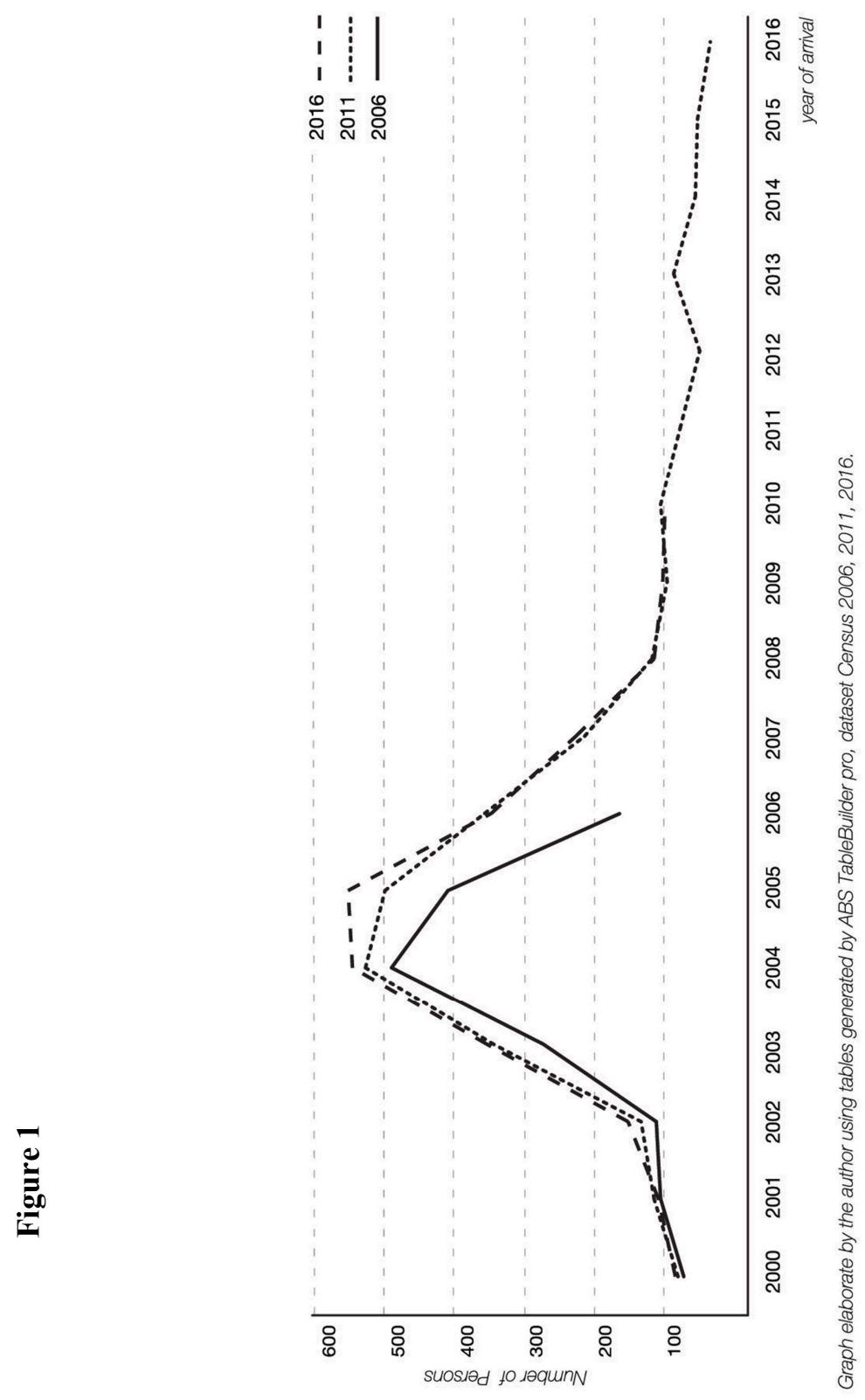




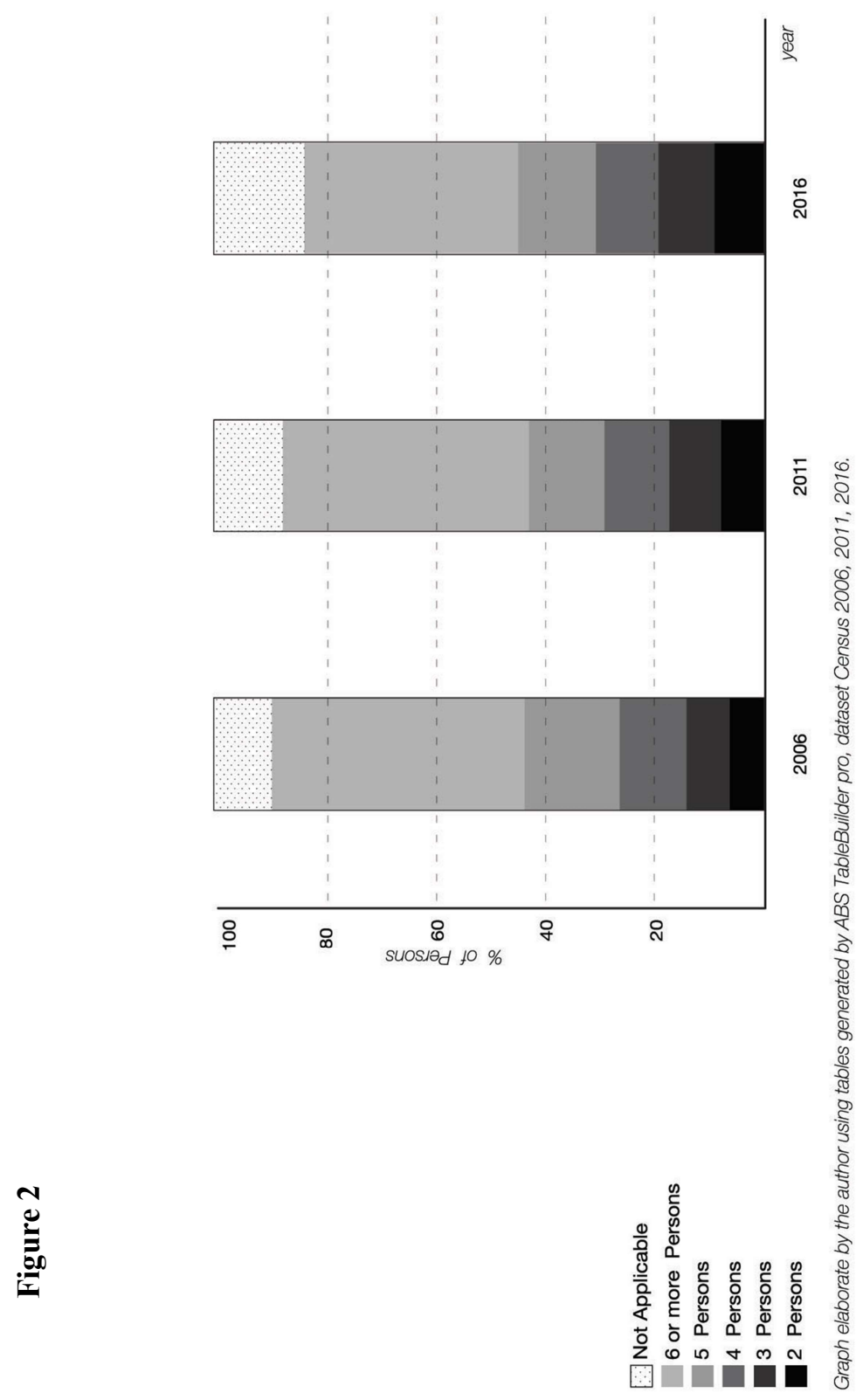




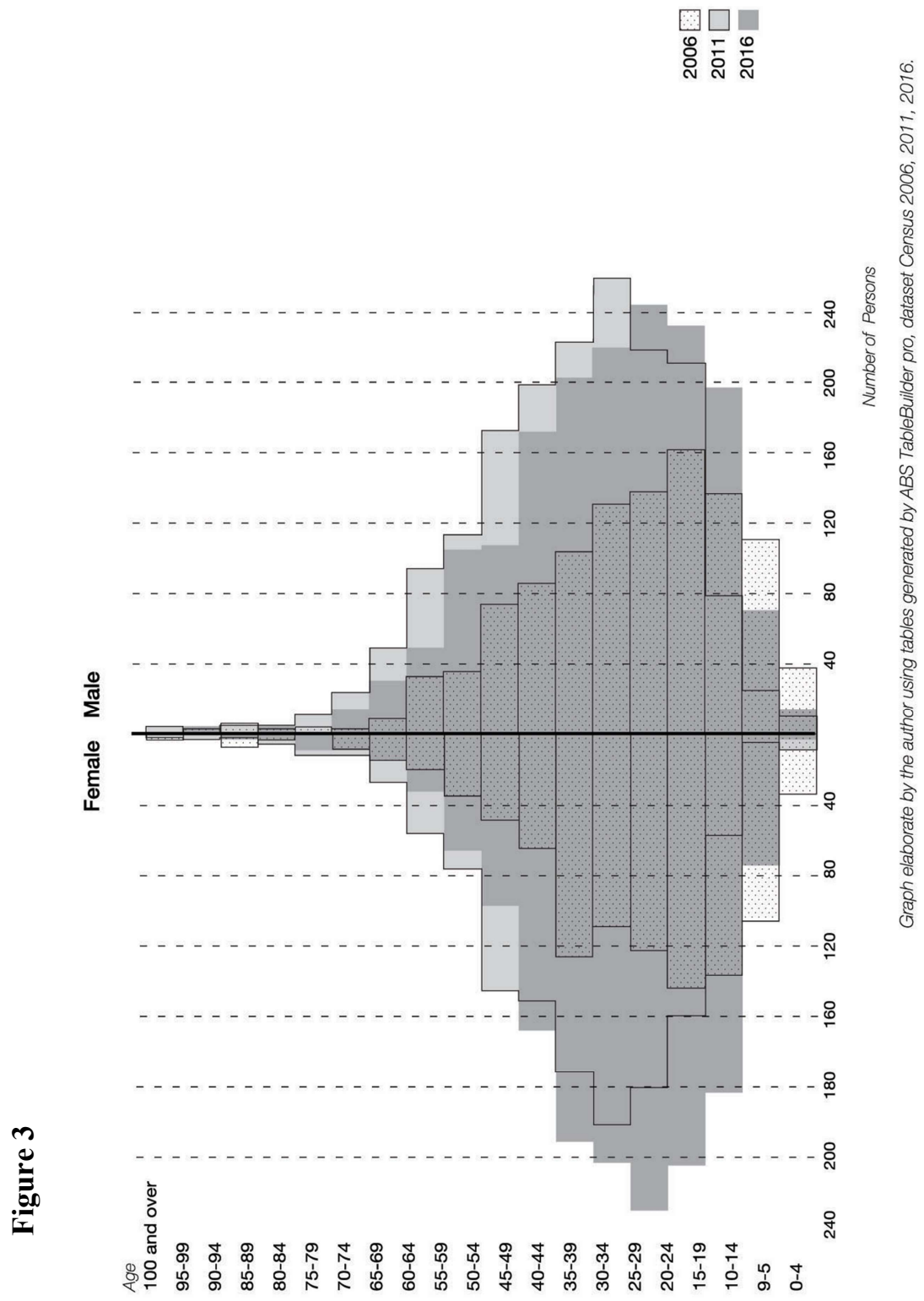




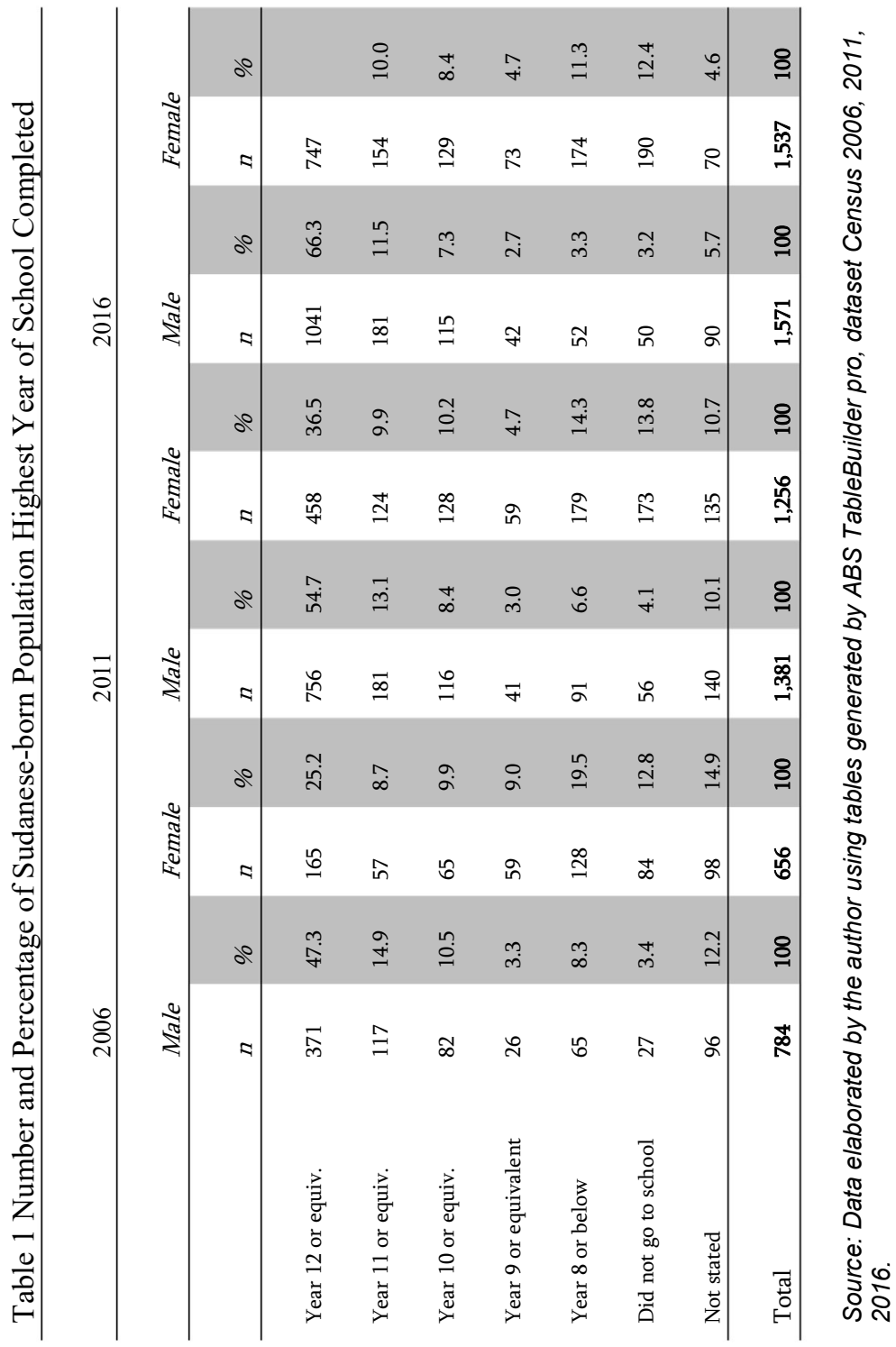




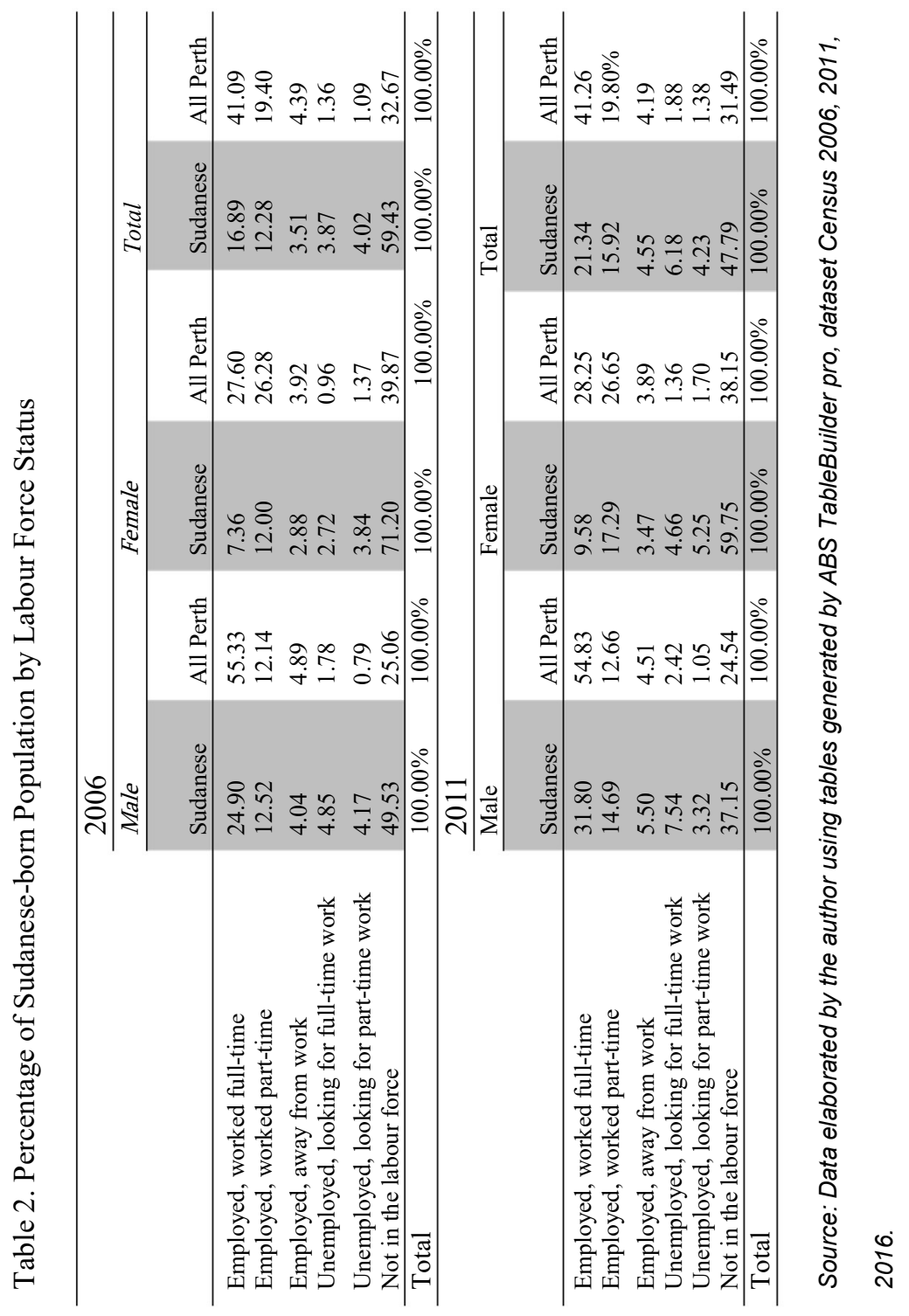


Table 3 Number and Percentage of Sudanese-born Population, Weekly Equivalised Total Household Income

\begin{tabular}{|c|c|c|c|c|c|}
\hline $\begin{array}{r}\text { Equivalised } \\
\text { disposable } \\
\text { income } \\
\text { Australia } \\
\end{array}$ & $\begin{array}{l}\text { Mean } \\
\text { income per } \\
\text { week }^{*}\end{array}$ & 2006 & $\mathrm{n}$ & $\%$ & \\
\hline \multirow{6}{*}{$\begin{array}{l}\text { Lowest } \\
\text { quintile }\end{array}$} & \multirow{6}{*}{288} & Negative income & 21 & $1.5 \%$ & \\
\hline & & Nil income & 4 & $0.3 \%$ & \\
\hline & & $\$ 1-\$ 149$ & 182 & $12.8 \%$ & \\
\hline & & $\$ 150-\$ 249$ & 384 & $27.1 \%$ & \\
\hline & & $\$ 250-\$ 399$ & 414 & $29.2 \%$ & $70.9 \%$ \\
\hline & & $\$ 400-\$ 599$ & 252 & $17.8 \%$ & \\
\hline \multirow{3}{*}{$\begin{array}{l}\text { Second } \\
\text { quintile }\end{array}$} & \multirow[t]{3}{*}{640} & $\$ 600-\$ 799$ & 92 & $6.5 \%$ & $95.2 \%$ \\
\hline & & $\$ 800-\$ 999$ & 34 & $2.4 \%$ & \\
\hline & & $\$ 1,000-\$ 1,299$ & 17 & $1.2 \%$ & \\
\hline \multirow[t]{2}{*}{$\begin{array}{r}\text { Third } \\
\text { quintile }\end{array}$} & 1,084 & $\$ 1,300-\$ 1,599$ & 12 & $0.8 \%$ & \\
\hline & & $\$ 1,600-\$ 1,999$ & 0 & $0.0 \%$ & \\
\hline \multirow{2}{*}{$\begin{array}{r}\text { Fourth } \\
\text { quintile } \\
\text { Highest } \\
\text { quintile } \\
\text { All } \\
\text { households } \\
\end{array}$} & 1,658 & $\$ 2,000$ or more & 5 & $0.4 \%$ & \\
\hline & $\begin{array}{r}3,156 \\
1,366 \\
\end{array}$ & Total & 1,417 & & \\
\hline & & \multicolumn{4}{|l|}{2011} \\
\hline \multirow{7}{*}{$\begin{array}{l}\text { Lowest } \\
\text { quintile }\end{array}$} & & Negative income & 25 & $1.0 \%$ & \\
\hline & & Nil income & 71 & $2.8 \%$ & \\
\hline & & $\$ 1-\$ 199(\$ 1-\$ 10,399)$ & 433 & $17.2 \%$ & \\
\hline & & $\$ 200-\$ 299(\$ 10,400-\$ 15,599)$ & 422 & $16.8 \%$ & $41.7 \%$ \\
\hline & & $\$ 300-\$ 399(\$ 15,600-\$ 20,799)$ & 380 & $15.1 \%$ & \\
\hline & 392 & $\$ 400-\$ 599(\$ 20,800-\$ 31,199)$ & 596 & $23.7 \%$ & \\
\hline & & $\$ 600-\$ 799(\$ 31,200-\$ 41,599)$ & 307 & $12.2 \%$ & $89.0 \%$ \\
\hline \multirow[t]{2}{*}{$\begin{array}{l}\text { Second } \\
\text { quintile }\end{array}$} & 855 & $\$ 800-\$ 999(\$ 41,600-\$ 51,999)$ & 136 & $5.4 \%$ & \\
\hline & & $\$ 1,000-\$ 1,249(\$ 52,000-\$ 64,999)$ & 73 & $2.9 \%$ & \\
\hline Third quintile & 1,448 & $\begin{array}{l}\$ 1,250-\$ 1,499(\$ 65,000-\$ 77,999) \\
\$ 1,500-\$ 1,999(\$ 78,000-\end{array}$ & 37 & $1.5 \%$ & \\
\hline $\begin{array}{l}\text { Fourth } \\
\text { quintile } \\
\text { Highest }\end{array}$ & 2,236 & $\begin{array}{l}\$ 103,999) \\
\$ 2,000 \text { or more }(\$ 104,000 \text { or } \\
\text { more })\end{array}$ & 17 & $0.7 \%$ & \\
\hline $\begin{array}{r}\text { quintile } \\
\text { All } \\
\text { households } \\
\end{array}$ & $\begin{array}{l}4,654 \\
\mathbf{1 , 8 4 5} \\
\end{array}$ & Total & 2,511 & & \\
\hline
\end{tabular}




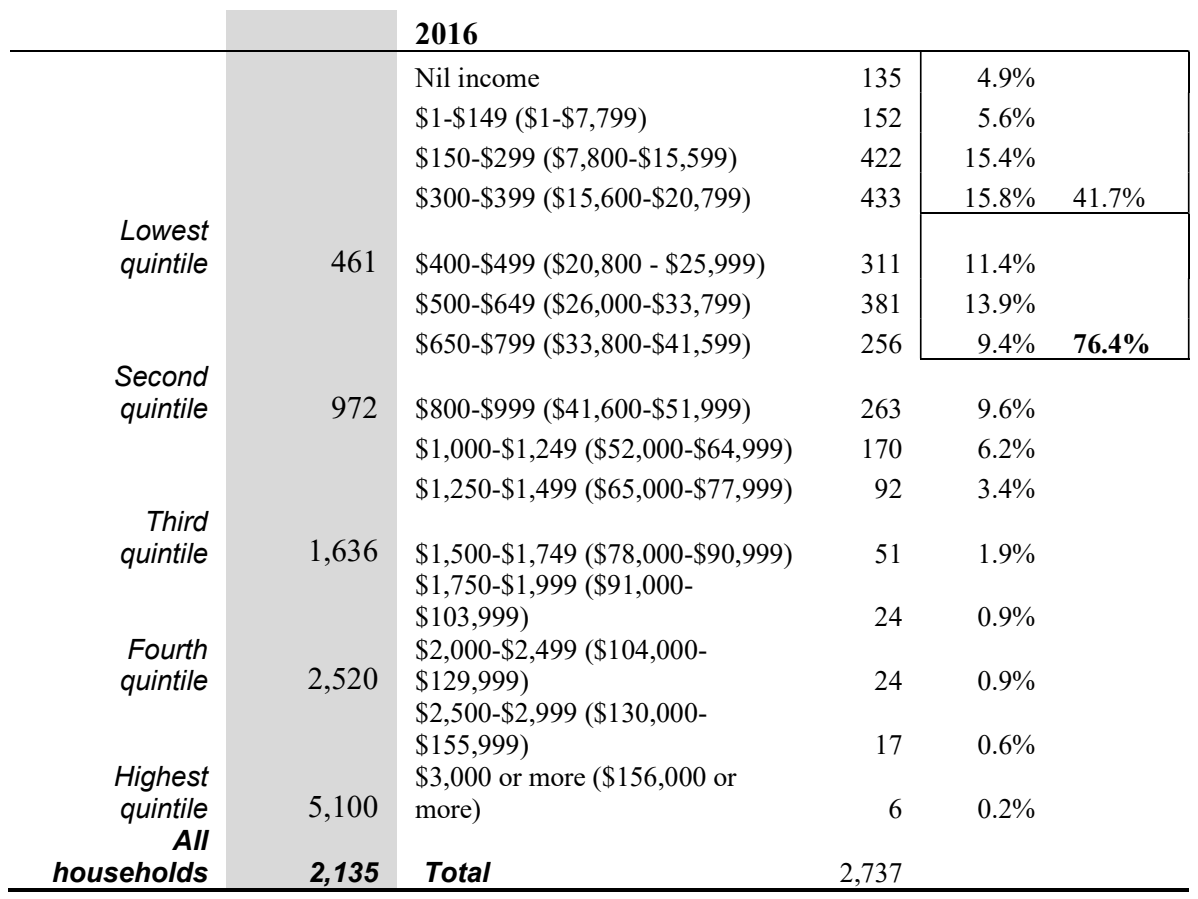




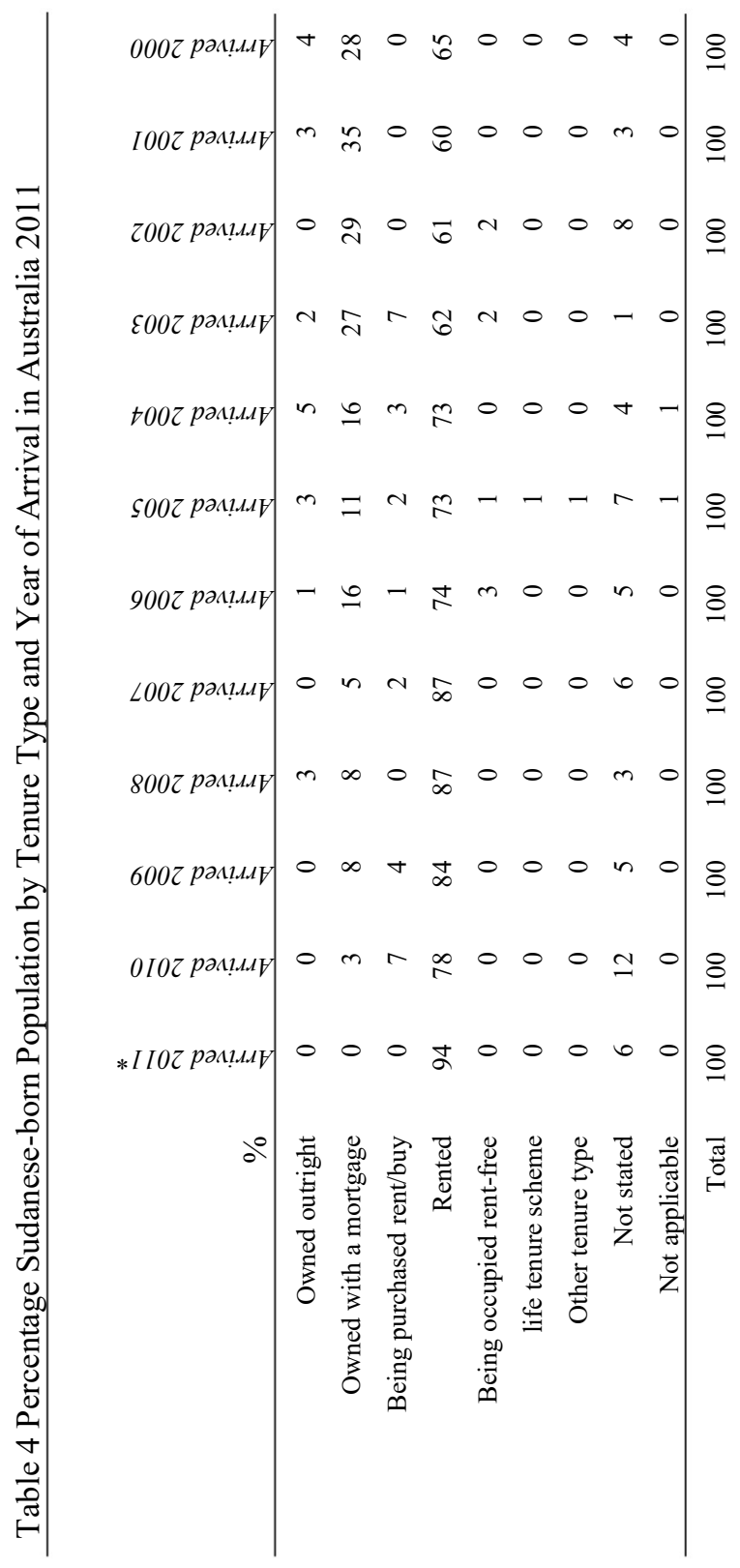




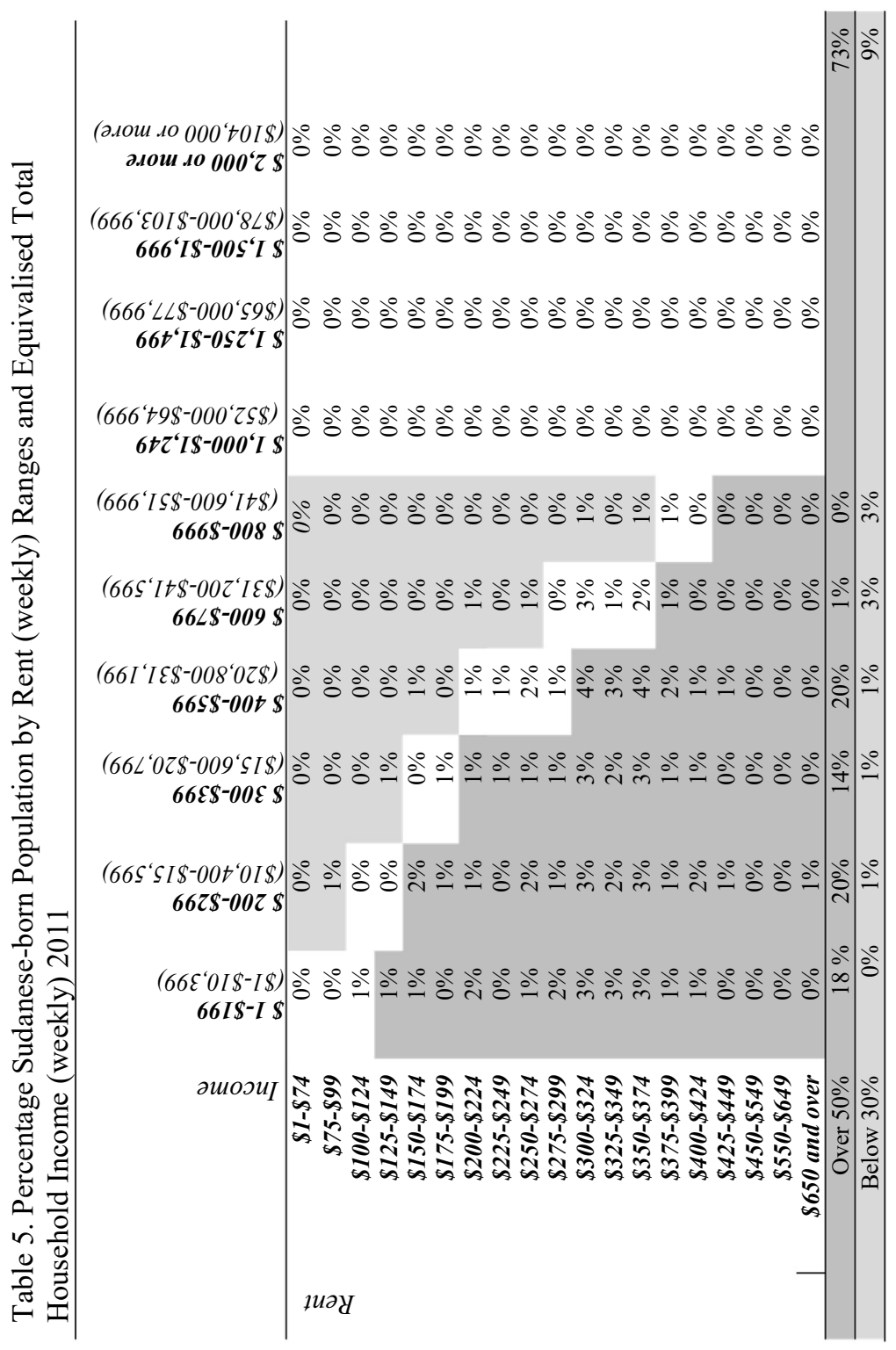




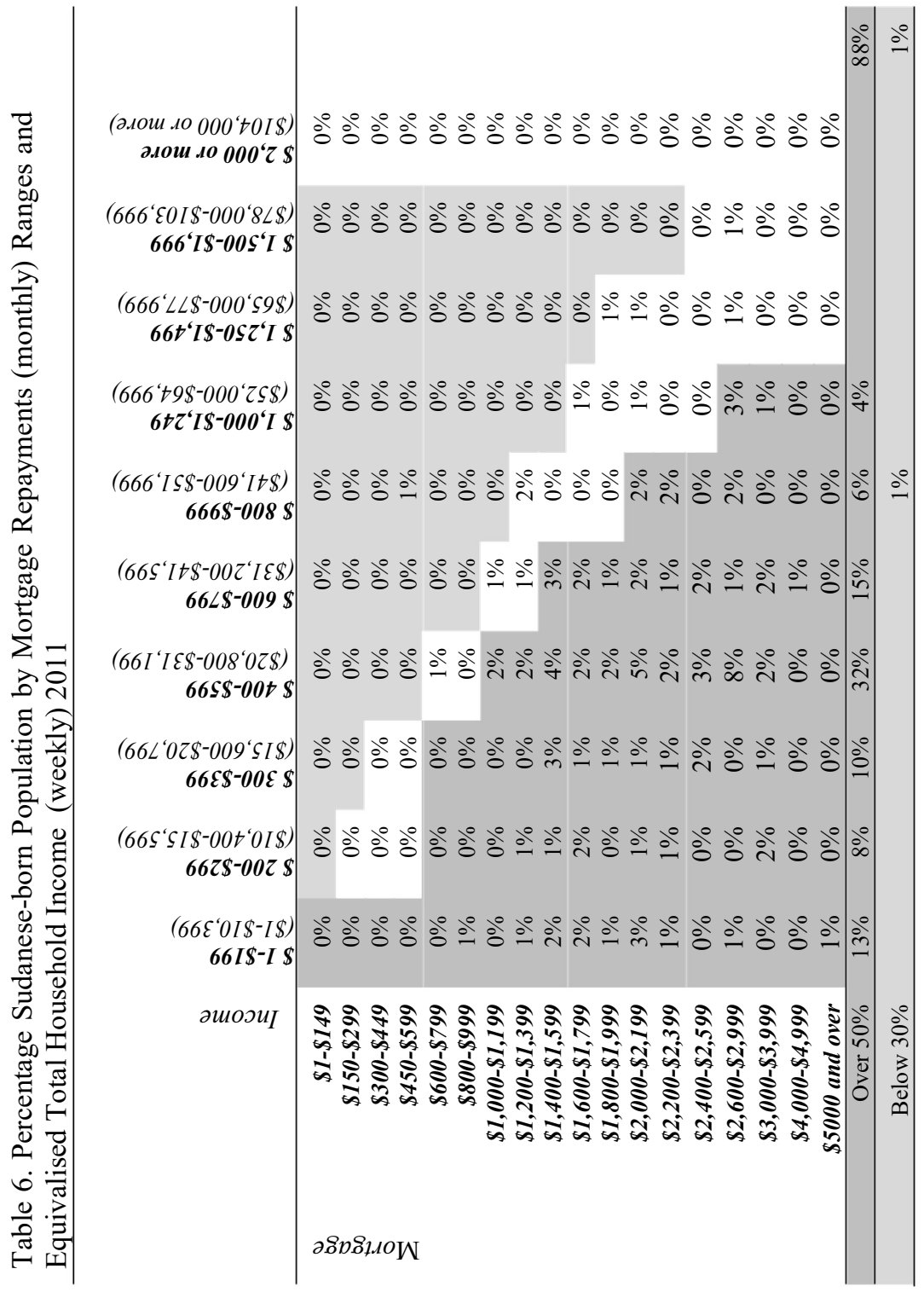


Table 7. Number and Percentage of Sudanese-born Population, Weekly Equivalised Total Household Income

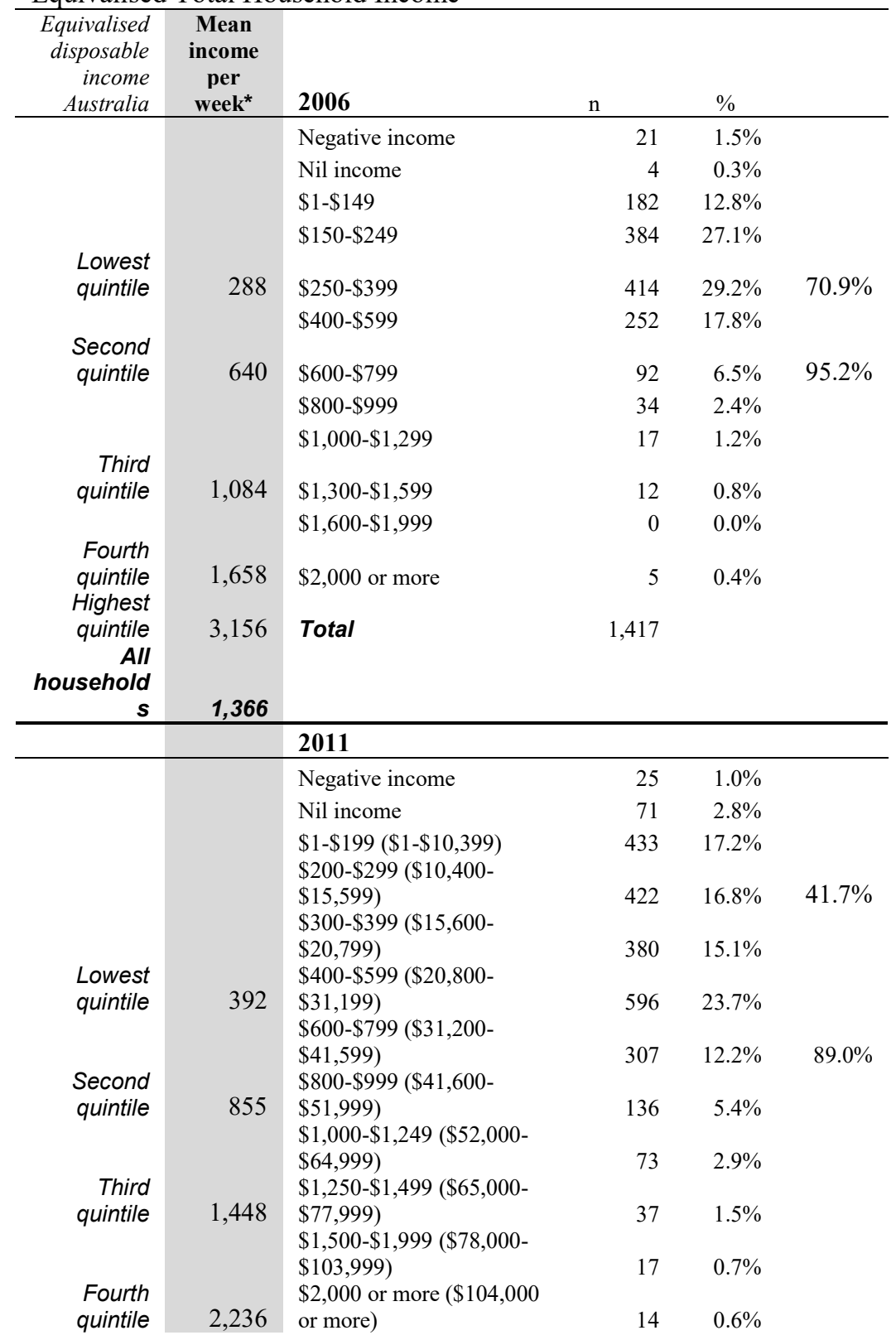




\begin{tabular}{|c|c|c|c|c|c|}
\hline $\begin{array}{r}\text { Highest } \\
\text { quintile } \\
\text { All } \\
\text { household } \\
\mathrm{s}\end{array}$ & $\begin{array}{r}4,654 \\
1,845 \\
\end{array}$ & Total & 2,511 & & \\
\hline & & 2016 & & & \\
\hline & & Nil income & 135 & $4.9 \%$ & \\
\hline & & $\$ 1-\$ 149(\$ 1-\$ 7,799)$ & 152 & $5.6 \%$ & \\
\hline & & $\$ 15,599)$ & 422 & $15.4 \%$ & \\
\hline & & $\begin{array}{l}\$ 300-\$ 399(\$ 15,600- \\
\$ 20,799)\end{array}$ & 433 & $15.8 \%$ & $41.7 \%$ \\
\hline $\begin{array}{l}\text { Lowest } \\
\text { quintile }\end{array}$ & 461 & $\begin{array}{l}\$ 400-\$ 499(\$ 20,800- \\
\$ 25,999)\end{array}$ & 311 & $11.4 \%$ & \\
\hline & & $\begin{array}{l}\$ 500-\$ 649(\$ 26,000- \\
\$ 33,799) \\
\$ 650-\$ 799(\$ 33,800-\end{array}$ & 381 & $13.9 \%$ & \\
\hline & & $\$ 41,599)$ & 256 & $9.4 \%$ & $76.4 \%$ \\
\hline $\begin{array}{l}\text { Second } \\
\text { quintile }\end{array}$ & 972 & $\begin{array}{l}\$ 800-\$ 999(\$ 41,600- \\
\$ 51,999) \\
\$ 1000-\$ 1.249(\$ 52,000-\end{array}$ & 263 & $9.6 \%$ & \\
\hline & & $\begin{array}{l}\$ 1,000-\$ 1,249(\$ 5<, 000- \\
\$ 1,250-\$ 1,499(\$ 65,000-\end{array}$ & 170 & $6.2 \%$ & \\
\hline & & $\$ 77,999)$ & 92 & $3.4 \%$ & \\
\hline $\begin{array}{r}\text { Third } \\
\text { quintile }\end{array}$ & 1,636 & $\begin{array}{l}\$ 1,500-\$ 1,749(\$ 78,000- \\
\$ 90,999) \\
\$ 1,750-\$ 1,999(\$ 91,000-\end{array}$ & 51 & $1.9 \%$ & \\
\hline Fourth & & $\$ 103,999)$ & 24 & $0.9 \%$ & \\
\hline quintile & 2,520 & $\begin{array}{l}\$ 2,000-\$ 2,499(\$ 104,000- \\
\$ 129,999) \\
\$ 2500-\$ 2,999(\$ 130000-\end{array}$ & 24 & $0.9 \%$ & \\
\hline & & $\$ 155,999)$ & 17 & $0.6 \%$ & \\
\hline $\begin{array}{r}\text { Highest } \\
\text { quintile } \\
\text { All } \\
\text { household }\end{array}$ & 5,100 & $\begin{array}{l}\$ 3,000 \text { or more }(\$ 156,000 \\
\text { or more) }\end{array}$ & 6 & $0.2 \%$ & \\
\hline$s$ & 2,135 & Total & 2,737 & & \\
\hline
\end{tabular}

* Note - Further data elaborated from the author using ABS census databases 2006, 2011, 2016 are available from the author upon request. 


\section{References}

ABS (Australian Bureau of Statistics). 2006a. Average weekly earnings. Cat. 6302.0.http://www.ausstats.abs.gov.au/Ausstats/subscriber.nsf/0/6EB 1862D8B3236ECCA2572270015ED95/\$File/63020 Aug\%202006. pdf

ABS 2006b. Census of population and housing. April. TableBuilder.

ABS. 2011a. Average weekly earnings. 6301.0 http://www.ausstats .abs.gov.au/ausstats/meisubs.nsf/0/2C216DAB631C5CC8CA2579A C000D5DBE/\$File/63020 nov\%202011.pdf

ABS. 2011b. Census dictionary, 2011. 2901.0. http://www.abs.gov.au/ ausstats/abs@.nsf/Lookup/2901.0Main\%20Features802011/\$FILE/2 011\%20Census\%20Dictionary\%2027102011.pdf

ABS 2011c. Census of population and housing. April. TableBuilder.

ABS. 2015. Standards for income variables. 1287.0 http:/www.abs.gov.au/ ausstats/abs@.nsf/Lookup/by\%20Subject/1287.0 Jun\%202015 Mai $\underline{\mathrm{n} \% 20 \text { Features } \sim \text { Equivalised } \% 20 \text { Household } \% 20 \text { Income } 24}$

ABS. 2016a. Average weekly earnings, Australia. 6302.0. https://www.abs. gov.au/AUSSTATS/abs@.nsf/Lookup/6302.0Main+Features1May\% 202016? OpenDocument

ABS 2016b. Census of population and housing. April. TableBuilder.

ABS. 2017a. Household income and income distribution 2015-16. Table 1. Housing occupancy and costs, Australia, 1994-95 to 2015-16. 6523.0. https://www.abs.gov.au/AUSSTATS/abs@.nsf/DetailsPage/4130.02 015-16? OpenDocument

ABS. 2017b. Household income and income distribution 2015-16. Table 18. Housing occupancy and costs, Western Australia, 1994-95 to 201516.6523.0.http://www.abs.gov.au/AUSSTATS/abs@.nsf/DetailsPag e/4130.0201516? OpenDocument

Australian Human Rights Commission. 2010. In our own words. African Australians: A review of the human rights and social inclusion issues. Sydney: Australian Human Right Commission.

Azriel, I. L. 2010. 'Migrants' houses: The importance of housing form in migrants' settlement'. Doctoral dissertation, University of Melbourne.

Colic-Peisker, V., and Tilbury, F. 2008. Being Black in Australia: A case study of intergroup relations. Race \& Class, 49(4), 38-56.

Dhanji, S. 2010. Social or unsocial? The linkage between accommodation, health and well-being among former Horn of Africa and Sudanese refugees living in Australia. Australasian Review of African Studies, 31(1), 106-136. 
Demographia. 2018. 14th Demographia International Housing Affordability Survey. http://demographia.com/media_rls 2018.pdf

DIAC (Department of Immigration and Citizenship). 2007. Sudanese community profile. Canberra: Department of Immigration and Citizenship.

DSS (Department of Social Services). 2017. Settlement services for humanitarian entrants [webpage] last Modified 7 February 2017. www.dss.gov.au/settlement-and-multicultural-affairs/publications/ settlement-services-for-humanitarian-entrants\#where do refugees

DSS. 2016. Beginning a life in Australia (BaLIA). https://www. dss.gov.au/our-responsibilities/settlement-services/beginning-a-lifein-australia

DSS. 2014. Community Information Summary Sudan-born. www.dss.gov.au/sites/default/files/documents/02_2014/sudan.pdf

Fozdar, F., and Hartley, L. 2012. Refugees in Western Australia: Settlement and integration. Perth: Metropolitan Migrant Resource Centre Inc.

Fozdar, F., and Hartley, L. 2013. Housing and the creation of home for refugees in Western Australia. Housing, Theory and Society, 31(2), 148-173.

Fozdar, F., and Hartley, L. 2013a. Refugee resettlement in Australia: What we know and need to know. Refugee Survey Quarterly, 32(3), 23-51.

Galligan, B., Boese, M., and Phillips, M. 2014. Becoming Australian: Migration, settlement, citizenship. politics and policy series. Carlton: Melbourne University Press.

Graham, S., and Connell, J. 2006. Nurturing relationships: The gardens of Greek and Vietnamese migrants in Marrickville, Sydney. Australian Geographer, 37(3), 375-393.

Hadjiyanni, T. 2007. Bounded choices: Somali women constructing difference in Minnesota housing. Journal of Interior Design, 32(2), 13-27.

Hart, C., and Maiden, S. 2007. Race to point finger of blame. The Australian. October 6, 2007. http://www.theaustralian.com.au/news/inquirer/ race-to-point-finger-of-blame/news-story/1e49ed9ad27f5240ebac8c9 $\mathrm{d} 5 \mathrm{~b} 7 \mathrm{ee} 311$

Head, L., Muir, P., and Hampel, E. 2004. Australian backyard gardens and the journey of migration. Geographical Review, 94(3), 326-347.

Hugo, G. 2011. Economic, social and civic contributions of first and second generation humanitarian entrants. Canberra: Department of Immigration and Citizenship. 
Housing Authority. Government of Western Australia. 2010. Affordable housing strategy 2010-2020: Opening Doors to Affordable Housing. Perth: Department of Housing.

Housing Authority. Government of Western Australia. 2007. 2006-07 Annual Report. Department of Housing and Works. http://www.housing.wa.gov.au/HousingDocuments/Department_of Housing and Works Annual Report 2006 2007.pdf

Jacobs, J. 2004. Too many houses for a home: Narrating the house in the Chinese Diaspora. In S. Cairns (Ed.) Drifting: Architecture and Migrancy, 164-183. London: Routledge.

Jacobs, K. 2011. Experience and representation: Contemporary perspectives on migration in Australia. Farnham, Surrey, England; Burlington, VT Ashgate.

Kiliçkiran, D. 2003. Migrant homes: ethnicity, identity and domestic space culture. In S. Menin (Ed.) Constructing place: Mind and matter (pp. 99-110). London: Routledge.

Lejukole, J. 2013. Falling through the cracks: Southern Sudanese refugees' experiences of housing and accommodation shortage in South Australia. In A. M. Harris, T. Lyons and J. M. Marlowe (Eds.), South Sudanese Diaspora in Australia and New Zealand: Reconciling the Past with the Present, (pp. 116-128). Newcastle upon Tyne: Cambridge Scholars.

Madden, D., and Marcuse., P. 2016. In defence of housing. London, New York: Verso.

OMI (Office of Multicultural Interests). 2009. Settlement issues for African humanitarian entrants in Western Australia: Implementation Report. Final Report. Perth: Government of Western Australia, Office of Multicultural Interests.

Perugia, F. 2017. Translating housing affordability policies and planning reforms in housing stock: The missed opportunity for the Perth Metropolitan Region (WA). Australian Planner, 54(4), 203-214.

Pittaway, E., Muli, C., and Shteir, S. 2009. 'I have a voice-hear me!' Findings of an Australian study examining the resettlement and integration experience of refugees and migrants from the Horn of Africa in Australia. Refuge, 26(2), 133-146.

RCOA (Refugee Council of Australia). 2013. Housing and issues for refugees and asylum seekers in Australia: A literature review. https://www.refugeecouncil.org.au/r/rpt/1309 HousingLitRev.pdf

Robinson, J. 2013. People of Sudanese heritage living in Australia: Implications of demography for individual and community resilience. 
In A. M. Harris, T. Lyons and J. M. Marlowe (Eds.), South Sudanese Diaspora in Australia and New Zealand: Reconciling the Past with the Present (pp. 12-47). Newcastle upon Tyne: Cambridge Scholars.

SCOA (Settlement Council of Australia). 2015. National Settlement Services Outcomes Standards Framework.

Shakespeare-Finch, J., and Wickham, K. 2009. Adaptation of Sudanese refugees in an Australian context: Investigating helps and hindrances. International Migration, 48(1), 23-46.

Strang, A., and Ager, A. 2008. Understanding integration: A conceptual framework. Journal of Refugee Studies, 21(2), 166-191.

UN Committee on Economic Social and Cultural Rights. 1991. General Comment No. 4: The Right to Adequate Housing (Art. 11 (1) of the Covenant). E/1992/23. www.refworld.org/pdfid/47a7079a1.pdf

UNHCR (United Nations High Commissioner for Refugees) (2002). Refugee resettlement: An international handbook to guide reception and integration.https://www.unhcr.org/en-au/protection/resettlement/4a2 cfe336/refugee-resettlement-international-handbook-guide-reception -integration.html 